\title{
On small quadrupedal ornithopod tracks in Jurassic-Cretaceous transition intertidal deposits (El Castellar, Teruel, Spain)
}

\author{
Luis ALCALA*, Luis MAMPEL, Rafael ROYO-TORRES \& Alberto COBOS
}

Fundación Conjunto Paleontológico de Teruel-Dinópolis/Museo Aragonés de Paleontología. Avda. Sagunto s/n, 44002 Teruel (Spain); alcala@fundaciondinopolis.org; mampel@fundaciondinopolis.org; royo@dinopolis.com; cobos@dinopolis.com

* Corresponding author

Alcalá, L., Mampel, L., Royo-Torres, R. \& Cobos, A. 2014. On small quadrupedal ornithopod tracks in Jurassic-Cretaceous transition intertidal deposits (El Castellar, Teruel, Spain). [Icnitas de pequeños ornitópodos cuadrúpedos en depósitos intermareales del tránsito Jurásico-Cretácico (El Castellar, Teruel, España)]. Spanish Journal of Palaeontology, 29 (2), $183-190$.

Manuscript received 09 August 2013

Manuscript accepted 04 December 2013

(C) Sociedad Española de Paleontología ISSN 2255-0550

\section{ABSTRACT}

The study of an undescribed part of the El Pozo tracksite in El Castellar (Teruel, Spain) has revealed two new trackways made by small ornithopods showing new evidences of basal ornithopod pes and manus track morphologies in the Jurassic-Cretaceous transition. The site lies within the Villar del Arzobispo Formation, which was deposited during the Tithonian-Berriasian in an environment under the influence of tides. The pes tracks are small tridactyl tracks, the digits are similar in size, and the heel is open and rounded. The presence of oval manus tracks in front of the tridactyl tracks in one of the trackways confirms that the dinosaur was a quadrupedal. Probably, the trackmaker dinosaur is a representative of the dryosaurid or of the basal Ankylopollexia clades. These tracks are smaller than those described for the Las Cerradicas site, also located in Teruel and in the same formation; consequently, these tracks from El Pozo site constitute some of the smallest ornithopod trackways with quadrupedal locomotion ever described in the world. In addition, in the same tracksite bed, there are some poorly preserved tracks attributed to big quadrupedal dinosaurs.

Keywords: Ornithopod, tracksite, Villar del Arzobispo Formation, Tithonian-Berriasian, Iberian Range.

\section{RESUMEN}

El estudio de una parte no descrita del yacimiento de icnitas de El Pozo en El Castellar (Teruel, España) revela dos rastros producidos por pequeños ornitópodos que aportan nuevos datos acerca de la morfología de las huellas de pies y manos de ornitópodos basales en la transición Jurásico-Cretácico. El yacimiento se sitúa en la Formación Villar del Arzobispo, que se depositó durante el Titoniense-Berriasienseen un ambiente bajo influencia mareal. Las icnitas del pie son pequeñas huellas tridáctilas, con los dígitos de tamaño similar y el talón redondeado. La presencia en uno de los rastros de huellas ovaladas de manos delante de las tridáctilas confirma que el dinosaurio era cuadrúpedo. Probablemente, el dinosaurio productor es un representante del grupo de los driosáuridos o de los Ankylopollexia basales. Estas huellas son menores que las descritas en el yacimiento de Las Cerradicas, también situado en Teruel y en la misma formación; en consecuencia, las icnitas del yacimiento de El Pozo forman parte de los rastros de ornitópodos con locomoción cuadrúpeda más pequeños descritos hasta el momento. Además, en la misma capa se encuentran algunas huellas mal conservadas atribuidas a grandes dinosaurios cuadrúpedos.

Palabras clave: Ornitópodos, yacimiento de huellas, Formación Villar del Arzobispo, Titoniense-Berriasiense, Cordillera Ibérica. 


\section{INTRODUCTION}

The Villar del Arzobispo Formation bears numerous dinosaur ichnite and vertebrate bone sites, some of which are type localities for new dinosaur taxa. Almost thirty dinosaur tracksites have been recorded in this formation in the Province of Teruel, Spain (Cobos, 2011; Alcalá et al., 2012) and one of them, CT-1 (El Castellar tracksite in the El Castellar municipality) is the type locality for the ichnospecies Deltapodus ibericus Cobos, Royo-Torres, Luque, Alcalá \& Mampel, 2010, which has been attributed to a stegosaurian trackmaker. Also, other tracks registered in the aforementioned formation have been attributed to a sauropod trackmaker (possibly a diplodocoidea), big sized theropods and thyreophorans at Ababuj AB-1 (Ababuj, Teruel) site (Alcalá \& Martín, 1995; RoyoTorres, 2009; Alcalá et al., 2012); at Aguilar 3 AG-3 (Aguilar del Alfambra, Teruel) three trackways attributed to stegosaurid trackmakers and five trackways made up of small tridactyl tracks attributed to bipedal dinosaurs, have also been described (Mampel et al., 2010-2011). In addition, there are tracks attributed to titanosauriforms at the Las Cerradicas site (Galve, Teruel) (Canudo et al., 2008; Castanera et al., 2011, 2012), where theropod and ornithopod trackmakers have been described (Pérez Lorente et al., 1997; Cobos et al., 2008; Lockley, 2009a; Castanera et al., 2013).

Surrounding El Castellar there are several palaeontological sites -totalling almost 50- which have provided both: direct remains (skeletal elements) and ichnites (tracks) of dinosaurs. The record of ichnites is characterized by tracks attributed to quadrupedal (sauropod, stegosaurid and ornithopod) and bipedal (theropod) dinosaurs. Three main dinosaur tracksites lie within the Villar del Arzobispo Formation, which was deposited during the TithonianBerriasian in an environment under tidal influence. Among the several hundreds of documented tracks at El Castellar we can highlight a trackway left by a large theropod (Alcalá et al., 2014), and at least another made by a stegosaurid (the holotype of Deltapodus ibericus, Cobos et al., 2010) both at site CT-1; and some of the largest sauropod tracks ever found in the Iberian Peninsula at site CT-3 and the El Mirador site. The characteristics of some prints suggest they may have been made by turiasaur eusauropods (Cobos et al., 2008; Royo-Torres, 2009; Alcalá et al., 2014).

The Villar del Arzobispo dinosaur tracksites in El Castellar were first reported by Alcalá et al. (2003), and partially described by Cobos et al. (2008, 2010, 2012), Royo-Torres (2009) and Alcalá et al. (2014). The general characteristics of the deposit have been described by Alcalá et al. (2014), who pointed out that all three sites (CT-1, CT-2, CT-3) contain well preserved tracks belonging to herbivorous and carnivorous dinosaurs, as well as a number of trackways. That paper describes the relationships between the sedimentary features at these sites and the characteristics of the tracks there recorded, and attempts to determine which sedimentological conditions best favour track formation and preservation, because sediment composition, structure and grain size could give rise to different track shapes and degrees of preservation. Indeed, the El Castellar sites show slightly different sedimentary features, and in fact, the CT-1 tracksite shows several substrate consistencies even within a single layer.

The facies of the El Castellar sites correspond to siliciclastic-carbonate tidal environments belonging to the Villar del Arzobispo Formation (middle Tithonianlower Berriasian) (Mas et al., 1984; Aurell et al., 1994; Bádenas et al., 2008-2009). This formation consists of limestones, sandstones and red claystones. Its maximum recorded thickness is $550 \mathrm{~m}$ in the type section, and it is more than $400 \mathrm{~m}$ thick in the El Castellar area (Aurell et al., 1994).

The characteristics of the Tithonian-Berriasian intertidal deposits at El Castellar suggest that sediment grain size and water content were the key factors which determined the recording of dinosaur tracks and trackways. The micritic mud derived from the pellets (which are common in some tracksites, aggregated and imbricated in fine layers, probably transported by currents) is a good track recorder, and preserves the details of tracks when it contained some water; on the contrary, biofilms seem not to have provided any special cohesion to the sediment surfaces of the El Castellar tracksites, and probably played no significant role in preventing the collapse of the track walls (Alcalá et al., 2014).

\section{DESCRIPTION}

The El Pozo CT-2 tracksite outcrops in small scattered patches of a limestone layer near El Castellar village (Fig. 1). The tracks are distributed at the upper part of a limestone stratum stretching more than $500 \mathrm{~m}^{2}$. There are at least three different limestone track surfaces: 1CT-2 the lower, 2CT-2 the intermediate and 3CT-2 the upper (Fig. 2). Just one of these dinosaur track assemblages, more specifically the outcrop 3CT-2, has not been described previously, in spite of having already been cited by Cobos et al. (2008), who assigned several manus and tridactyl pes prints to small quadrupedal ornithopods.

The 3CT-2 outcrop was found while undertaking conservation tasks carried out in 2007 at the El Pozo CT-2 site by Escuela Taller de Restauración Paleontológica II del Gobierno de Aragón and Fundación Conjunto Paleontológico de Teruel-Dinópolis. The cleaning of the site unveiled a new outcrop containing 25 dinosaur tracks on a grey limestone surface of nearly $4 \mathrm{~m}^{2}$, with an average direction of $\mathrm{N} 165 \mathrm{E}$ and $5^{\circ} \mathrm{W}$ dip, which was covered by vegetable matter. It is included in a zone declared an Asset 


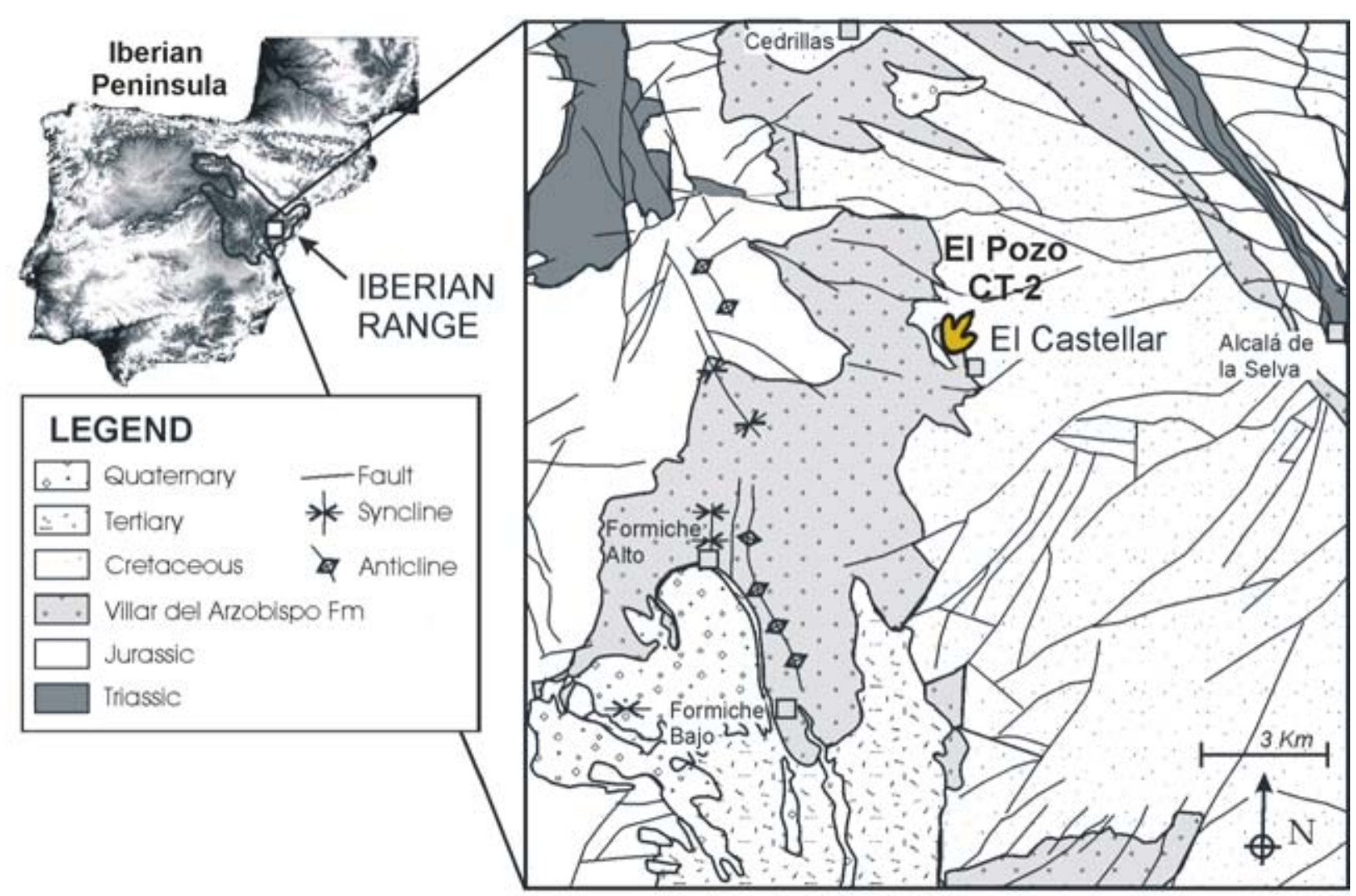

Figure 1. Placement of the El Pozo CT-2 site (El Castellar, Teruel, Spain) containing the 3CT-2 outcrop, which is studied in this paper.

of Cultural Interest (Bien de Interés Cultural, BIC) in the category "Conjunto de Interés Cultural", Palaeontological Zone, by Gobierno de Aragón in 2004. The El Castellar 3CT-2 dinosaur tracksite was surveyed and the dimensions and distributions of tracks recorded using a Trimble 5600 Plus topographical total station. The data gathered were then mapped using ArcView software (Fig. 3). This small part of CT-2 was covered to avoid damage, and casts of the tracks are held at the Museo Aragonés de Paleontologíal Fundación Conjunto Paleontológico de Teruel-Dinópolis.

This paper aims to characterize the dinosaur tracks from 3CT-2 outcrop in order to widen the existing information on quadrupedal trackways attributed to small sized ornithopod trackmakers, as this kind of trackways is scarce in the fossil record (Lockley \& Meyer, 1999) and even more during the Jurassic-Cretaceous transition.

We can see some few large isolated oval tracks (corresponding to manus and pes poorly preserved), an a group of small tracks composed by: a trackway with an association of pairs of tridactyl pes and oval manus, a tridactyl trackway made up of four consecutive tracks, and several tracks from small tridactyl pes and small isolated oval manus. We focus on the trackway with three consecutive very small pairs of tridactyl pes associated with rounded manus (measurements in Table 1). These are smaller than those of the quadrupedal trackway attributed to the small ornithopod described from Las Cerradicas, Galve, Teruel, by Pérez-Lorente et al. (1997).

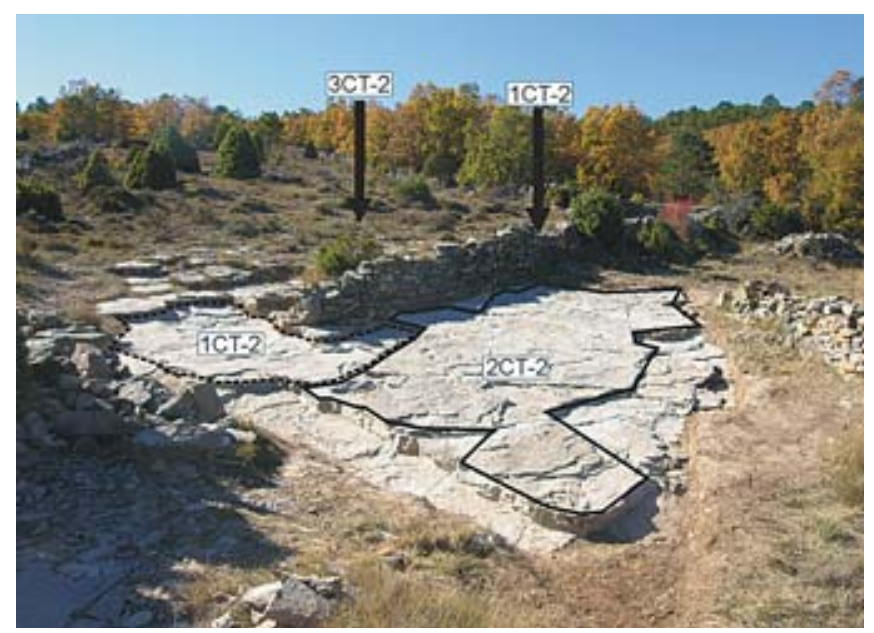

Figure 2. General view of the El Pozo CT-2 site with its three different levels (modified from Alcalá et al., 2014). Notice the placement of 3CT-2, covered to favour its preservation. 
Table 1. Measurements (in $\mathrm{cm}$ ) of the best preserved tracks and trackways recognised in 3CT-2. Abbreviations: L, track; W, track width; PL, pace length; SL, stride length; ANG, pace angulation; eTW, external trackway width.

\begin{tabular}{lcccccccccccc}
\hline EL POZO 3CT-2 & L & W & L/W & LII & LIII & LIV & II^III & III^IV & PL & SL & ANG & eTW \\
\hline 3CT-2-2p & 11.8 & - & - & 8 & 11 & - & - & - & 28 & - & 156 & 10 \\
3CT-2-3p & 11.5 & 10 & 1.15 & 10 & 11 & 10.5 & 26 & 29 & 28 & 55 & 154 & 9 \\
3CT-2-3m & 3.5 & 3 & 1.16 & - & - & - & - & - & - & - & - & - \\
3CT-2-4p & $15 ?$ & $10 ?$ & $1.5 ?$ & 10 & 13.5 & 11 & 19 & 24 & 24 & 51 & 148 & 10 \\
3CT-2-4m & 4 & 2 & 2 & - & - & - & - & - & - & - & - & - \\
3CT-2-5p & 14 & 11.5 & 1.2 & 11 & 13 & 9 & 24 & 29 & 24 & 46 & - & 9 \\
3CT-2-5m & 4 & 4.1 & 0.9 & - & - & - & - & - & - & - & - & - \\
3CT-2-8p & 16 & 12 & 1.3 & 12 & 16 & 11 & 35 & 24 & - & - & - & - \\
3CT-2-13p & 17 & 13.5 & 1.2 & 9 & 17 & 9 & 32 & 30 & 43 & - & 153 & - \\
3CT-2-16p & 17 & 12 & 1.4 & 14 & 17 & 13 & 26 & 21 & 52 & 94 & - & - \\
3CT-2-19m & $15 ?$ & 26 & $0.6 ?$ & - & - & - & - & - & - & - & - & - \\
\hline
\end{tabular}

Within the first group -isolated large tracks- three oval tracks, partially preserved, corresponding to pes (3CT-2$20 \mathrm{p}$; 3CT-2-21p and 3CT-2-22p) and a manus track (3CT$2-19 \mathrm{~m}$ ) with half moon shape, broader than long and with digit I (pollex) slightly marked (Fig. 3) have been found. All represent undetermined quadrupedal dinosaurs.

The most interesting trackway is made up of eight small tracks (six of them associated in pairs of tridactyl pes-oval manus) (3CT-2-1p; 3CT-2-2p; 3CT-2-3p; 3CT2-3m; 3CT-2-4p; 3CT-2-4m; 3CT-2-5p and 3CT-2-5m; Figs 3,4$)$. Three consecutive pairs of tridactyl pes-oval manus are outstanding in this trackway. The pes tracks bear a rounded posterior ridge. The two best preserved tridactyl tracks show L/W 1.15 (3CT-2-3p) and 1.2 (3CT-2-5p) values. The digits are short and broad with a rounded to slightly pointed end (3CT-2-5p) although it is not completely sharp. Their degree of preservation allows us to distinguish the phalangeal pads in some of the tracks (especially 3CT-2-5p) and rounded, symmetric heel pads. However, hallux traces have not been identified in pes tracks. Following Lockley (2009b), the inward rotation of the pes observed in 3CT-2 trackways and the rounded, symmetric heel pads are typical features of ornithopod trackmakers. Regarding their measurements (Table 1), pes are longer $(11.5-14.0 \mathrm{~cm})$ than broad $(10.0-11.5 \mathrm{~cm})$ and digit III is slightly longer (11.0$13.5 \mathrm{~cm})$ than digits II $(8.0-11.0 \mathrm{~cm})$ and IV $(9.0-11.0$ $\mathrm{cm})$. The manus tracks display oval morphologies and are much smaller than the pes. The fact that the anterior (oval or sub-rounded) and posterior (tridactyl) autopod

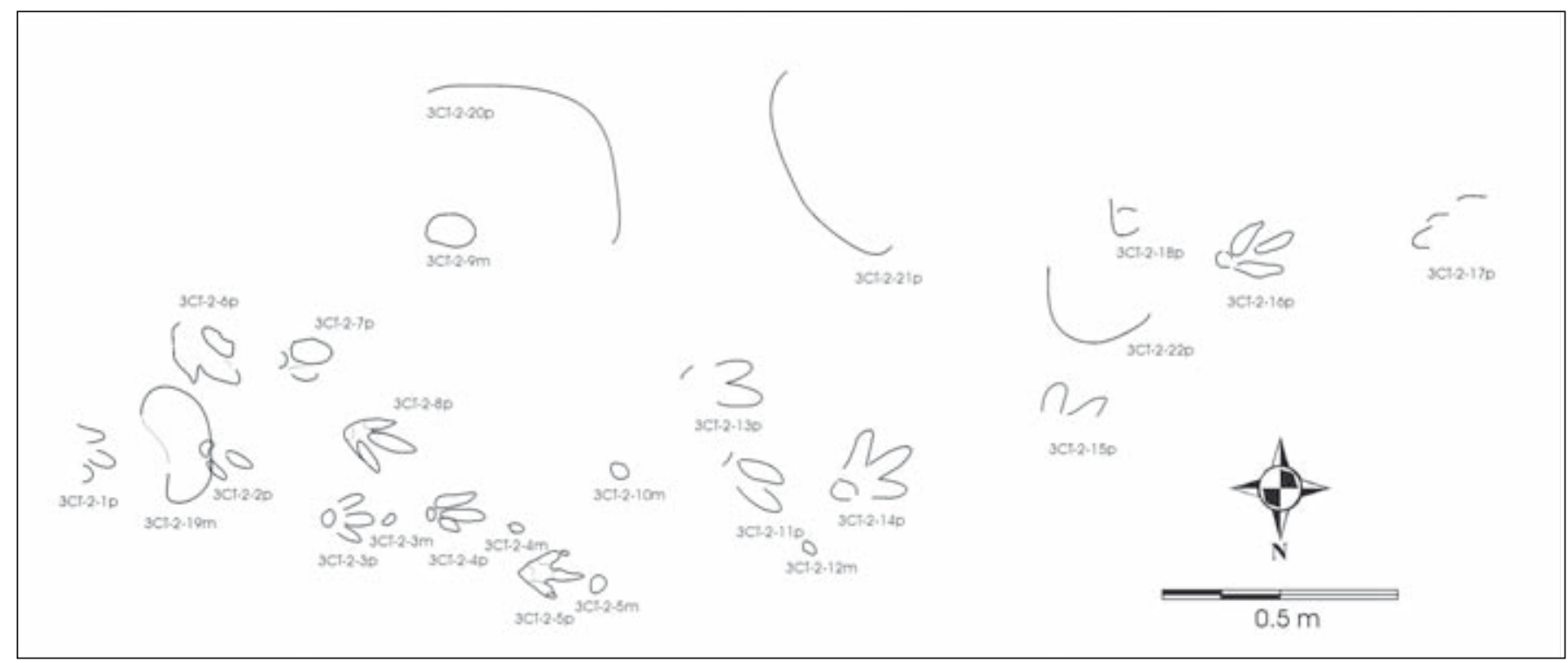

Figure 3. Cartography of the dinosaur tracks from 3CT-2 outcrop (El Pozo CT-2 site). 
tracks are found associated appears decisive for assigning them to a quadrupedal trackmaker (an ornithopod, most likely), although the tridactyl tracks, looking at them in isolation, present some characteristics which resemble, in a convergent way, theropod pes (as in Las Cerradicas; Lockley, 2009a, b). There are also two isolated tracks with their morphology and size similar to those aforementioned manus and possibly produced by the same ornithopod (3CT-2-10m and 3CT-2-12m). There is, as well, a badly preserved tridactyl trackway made up of four tridactyl tracks (3CT-2-13p; 3CT-2-15p; 3CT-2-16p and 3CT-2-17p) with morphology and size similar to the aforementioned trackway; but we have to stress that the manus tracks are not associated. The best preserved of the four prints (3CT$2-16 \mathrm{p}$ ) shows a $1.4 \mathrm{~L} / \mathrm{W}$ value. The digits traces bear a slightly pointed end, although it is not completely sharp.

Finally, there are some isolated tridactyl tracks (3CT2-6p; 3CT-2-7p; 3CT-2-8p, 3CT-2-11p, 3CT-2-14p, 3CT$2-18 p$ ) with different degrees of preservation. 3CT-2-8p (Figs 3,4 ) is a well preserved tridactyl pes with $\mathrm{L} / \mathrm{W}=1.3$ where digit III is a bit longer $(16 \mathrm{~cm})$ than digits II $(12 \mathrm{~cm})$ and IV $(11 \mathrm{~cm})$. The absence of manus tracks association and the occasional overlapping of morphologies between theropod and ornithopod tracks leaves the attribution to a definite trackmaker uncertain, although the similar characteristics of these tridactyl tracks to the quadrupedal trackway ones point to the fact that they belong to the same ornithopod trackmaker.

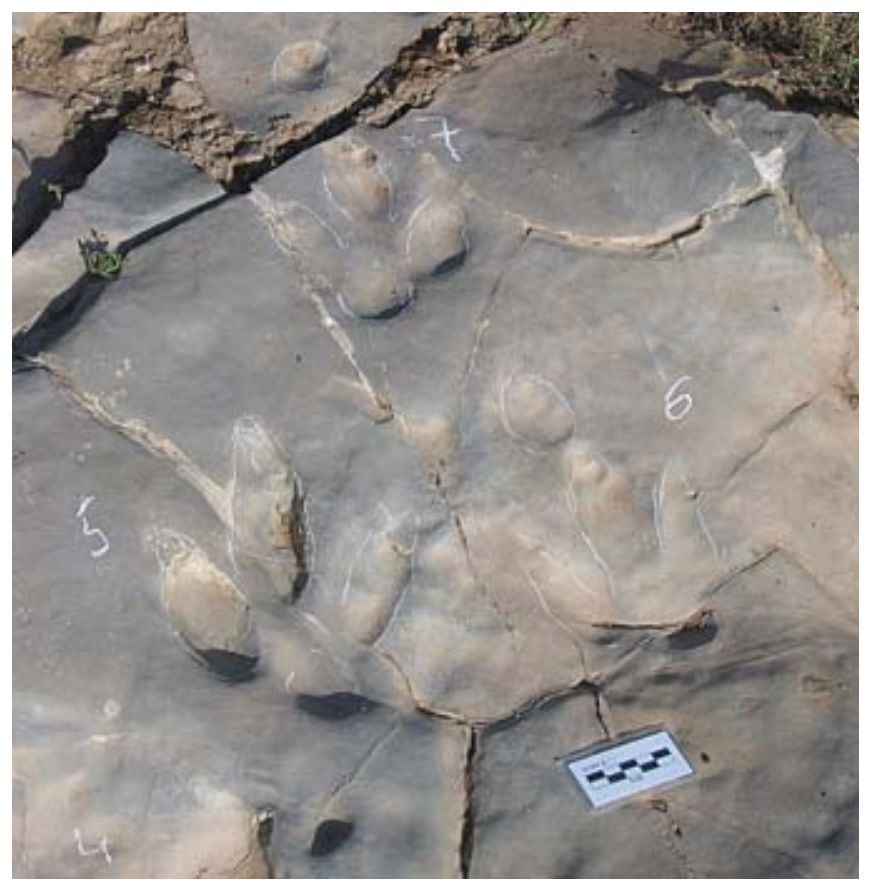

Figure 4. Ornithopod tracks details: 3CT-2-8p (marked as 5); $3 \mathrm{CT}-3-3 \mathrm{p}$ and 3CT-3-3m (marked as 6); and 3CT-2$4 \mathrm{p}$ and $3 \mathrm{CT}-2-4 \mathrm{~m}$ (marked as 7).

\section{DISCUSSION}

The typical characteristics used to distinguish theropod from ornithopod trackmakers are not well defined when identifying small tridactyl tracks (Marty, 2008; Lockley 2009b; Castanera et al., 2012). However, the presence of tridactyl tracks, with digits of a similar size and an open and rounded heel are typical features of ornithopod dinosaurs (Sarjeant et al., 1998). Besides, the identification of trackways composed by oval manus tracks in front of the tridactyl pes -proving that the trackmaker was quadrupeddemonstrate they cannot confidently be assigned to a theropod trackmaker but may represent ornithopod dinosaurs (Norman, 1980; Sarjeant et al., 1998). The register in 3CT2 of trackways composed just by hind limb tracks showing identical morphologies to those of the tridactyl tracks from the 3CT-2 quadrupedal trackways allows us to confidently attribute them -in spite of being a little bit larger- to the aforementioned ornithopod trackmaker.

The quadrupedalism with tridactyl pes and presence of manus tracks was proposed for the Styracosterna trackmakers by Carrano \& Wilson (2001). Nevertheless, the presence of nail marks on II-IV digits in hooves, characteristic of this clade (Carrano \& Wilson, 2001) is not clearly visible in the tracks from the El Pozo site: some marks are a bit sharp and others a bit round. Due to this variation, it is difficult to include the trackmaker within the Styracosterna clade, thus it is more sensible to assign it to a dryosaurid or to a basal Ankylopollexia.

To compare these tracks with the direct remains we have to point out that the register of ornithopod remains found in the Villar del Arzobispo Formation consist of a tooth, an ungual phalanx and a partially articulated hind left limb from Riodeva municipality (Royo-Torres et al., 2006; Gascó et al., 2013), three vertebral centra from the Cerrito del Olmo site in Alpuente, Valencia (Pereda-Suberbiola et al., 2009) and an isolated tooth from the "By Pass" site also in Alpuente, Valencia (Suñer \& Martín, 2009). In addition, cranial and postcranial ornithopod remains have been described from the Tithonian-?Berriasian Ciria Formation of Berdejo, Zaragoza (Royo-Torres et al., 2012). These Spanish Tithonian-Berriasian ornithopod remains were attributed to indeterminate basal ankylopollexians (Pereda-Suberbiola et al., 2009; Royo-Torres et al., 2012; Gascó et al., 2013) which could be related to the basal ankylopollexian Draconyx loureiroi from the Portuguese Tithonian of Lourinhã (Mateus \& Antunes, 2001), and to the camptosaurids described from the Portuguese Tithonian (Malafaia et al., 2010) and from the Spanish Berriasian (Pereda Suberbiola et al., 2006). The fact that basal Ankylopollexia direct remains are present would be consistent with the ichnological register from the El Pozo site (Cobos et al., 2008) and other tracksites in the Villar del Arzobispo Formation, such as Las Cerradicas (PérezLorente et al., 1997). 
Another primitive ornithopod, closely related to Dryosaurus, has also been identified in the Tithonian Andrés site (Malafaia et al., 2010). Dryosaurids exhibit unusually specialized and narrow feet (Norman, 2004) and according to the size of their pes (length $10-15 \mathrm{~cm}$; see fig 19.13 in Norman, 2004) it could also be a possible trackmaker of the described tracks. Thus, the 3CT-2 trackmaker would be a quadrupedal basal ornithopod: possibly a dryosaurid or a basal member of Ankyllopollexia (but out of the Styracosterna clade).

The Las Cerradicas site contains more than a hundred mapped tracks. The first description of the site, carried out by Pérez-Lorente et al. (1997), describes one of the trackways as belonging to an ornithopod and other three trackways, whose pes share similar characteristics, to possible orntithopods or theropods trackmakers (CuencaBescós et al., 1997). The attribution of the three doubtful trackways to theropod trackmakers was later confirmed by Pérez-Lorente (2004, 2009) and Canudo et al. (2005, 2008, 2010). Concerning this matter, Alcalá (2006) mentions that there is a diversity of criteria on the attribution of these three trackways to theropod or ornithopod tracks, in spite of the fact that in the original study by Pérez-Lorente et al. (1997) manus tracks are already mapped in the trackways attributed to theropods. Even more, the identification of the three parallel trackways as being left by theropods led some researchers to propound a gregarious behaviour of carnivorous dinosaurs during the Tithonian-Berriasian transition, specified in scientific papers (Pérez-Lorente, 2004, 2009; Canudo et al., 2008, 2010; Castanera et al., 2012) and in the information provided to explain the characteristics of the site to the public when it was open to the visitors by Gobierno de Aragón.

In spite of keeping in mind all the aforementioned facts, the four trackways with tridactyl pes from Las Cerradicas have been undoubtedly attributed to quadrupedal ornithopod trackmakers several times (Royo-Torres \& Cobos, 2007; FCPTD-IDPI, 2009; Lockley, 2009a; Cobos, 2011; Alcalá \& Cobos, 2012; Castanera et al., 2013). The lack of a complete pes-manus pairs association in some trackways from Las Cerradicas would be the consequence of the differential preservation of the ornithopod manus tracks, as detail Castanera et al. (2013).

The presence of tridactyl pes associated with manus tracks would be an evidence to propose an ornithopod trackmaker (Carrano \& Wilson, 2001) and it forces to rule a theropod trackmaker out, disregarding the interpretation that small theropods were gregarious in Galve during the Tithonian-Berriasian transition.

\section{CONCLUSIONS}

This is the first time that the dinosaur tracks from the El Pozo 3CT-2 outcrop are described. It is placed in the Villar del Arzobispo Formation (Tithonian-Berriasian) near El Castellar village (Teruel). Among the 25 recognised tracks there is an outstanding trackway made up of three consecutive pairs of tridactyl pes with their corresponding associated oval manus which is assigned to an ornithopod trackmaker with quadrupedal habits. The interest of the finding lies in the fact that the ornithopod manus tracks are scarce, and even scarcer in the case of small sized ornithopods, from the Jurassic-Cretaceous transition zone. These are some of the smallest quadrupedal ornithopod tracks ever described in the world.

\section{ACKNOWLEDGEMENTS}

This work is dedicated to the memory of our friend Jordi Maria de Gibert, not only an excellent palaeontologist but also an efficient scientific policy maker and a painstaking treasurer of the Society which publishes this journal. This research was performed with the authorization and financial support of the Dirección General de Patrimonio Cultural del Gobierno de Aragón (exp. 267/2007), plus funding from the Fundación Conjunto Paleontológico de Teruel-Dinópolis, Ministerio de Economía y Competitividad (project DINOTUR CGL2013-41295-P), FOCONTUR (Grupo de Investigación Consolidado E-62, Departamento de Industria e Innovación, Gobierno de Aragón and Fondo Social Europeo) and the Instituto Aragonés de Fomento. The paper was strengthened by technical reviews by Martin Lockley and José I. Ruiz-Omeñaca. Jaume Grau is thanked for assistance during field surveys.

\section{REFERENCES}

Alcalá, L. 2006. Los yacimientos turolenses de icnitas y el Conjunto Paleontológico Dinópolis. In: Actas simposio internacional huellas que perduran. Icnitas de dinosaurios: patrimonio y recurso. Fundación del Patrimonio Histórico de Castilla y León, Valladolid, p. 265-286.

Alcalá, L. \& Cobos, A. 2012. The Dinosaur Track Road in Teruel (Spain). In: Dinosaur tracks 2011 (eds Richter, A. \& Reich, M.). Universitätsverlag Göttingen, 13.

Alcalá, L. \& Martín, C. 1995. Huellas de dinosaurios en el Jurásico Superior de Ababuj (Teruel). Geogaceta, 17, 19-22.

Alcalá, L., Cobos, A. \& Royo, R. 2003. Icnitas de dinosaurio en El Castellar (Teruel). In: XIX Jornadas de la Sociedad Española de Paleontología. Morella, Castellón, p. 28-29. 
Alcalá, L., Cobos, A., Espílez, E., Gascó, F., Mampel, L., Martín Escorza, C. \& Royo-Torres, R. 2012. Icnitas de dinosaurios en la Formación Villar del Arzobispo de Ababuj (Teruel, España). Geogaceta, 5, 31-34.

Alcalá, L., Pérez-Lorente, F., Luque, L., Cobos, A., RoyoTorres, R. \& Mampel, L. 2014. Preservation of dinosaur footprints in shallow intertidal deposits of the JurassicCretaceous transition in the Iberian Range (Teruel, Spain). Ichnos, 21, 19-31.

Aurell, M., Mas, R., Meléndez, A. \& Salas, R. 1994. El tránsito Jurásico-Cretácico en la Cordillera Ibérica: relación tectónica-sedimentación y evolución paleogeográfica. Cuadernos de Geología Ibérica, 18, 369-396.

Bádenas, B., Aurell, M., Ipas, J. \& Espílez, E. 2008-2009. Las plataformas del final del Jurásico al suroeste de la provincia de Teruel: evolución de facies y secuencias de alta frecuencia. Teruel, 92, 67-96.

Canudo, J.I., Aurell, M., Barco, J.L., Cuenca-Bescós, G. \& Ruiz-Omeñaca, J.I. 2005. Los dinosaurios de la Formación Villar del Arzobispo (Titónico medio-Berriasiense inferior) en Galve (Teruel). Geogaceta, 38, 39-42.

Canudo, J.I., Pérez-Lorente, F., Badiola, A., Barco, J.L., Cruzado-Caballero, P., Díaz-Martínez, I., Gasca, J.M., Gómez-Fernández, D., Moreno-Azanza, M. \& HerreroGascón, J. 2008. Evidencia de gregarismo en pequeños dinosaurios saurópodos del Titónico-Berriasiense (Formación Villar del Arzobispo, Galve, Teruel). In: XXIV Jornadas de la Sociedad Española de Paleontología. Colunga, Asturias, p. 23-24.

Canudo, J.I., Badiola, A., Barco, J.L., Castanera, D., CruzadoCaballero, P., Díaz-Martínez, I., Gasca, J.M., MorenoAzanza, M., Puértolas, E., Rabal, R., Ramón, D., RuizOmeñaca, J.I., Sauqué, V. \& Cuenca-Bescós, G. 2010. 20 años ayudando a diseñar museos por Aragón. In: XI Jornadas Aragonesas de Paleontología. Ricla, Zaragoza, p. 111-134.

Carrano, M.T. \& Wilson, J.A. 2001. Taxon distributions and the tetrapod track record. Paleobiology, 27, 564-582.

Castanera, D., Barco, J.L., Díaz-Martínez, I., Herrero Gascón, J., Pérez-Lorente, F. \& Canudo, J.I. 2011. New evidence of a herd of titanosauriform sauropods from the lower Berriasian of the Iberian Range (Spain). Palaeogeography, Palaeoclimatology, Palaeoecology, 310, 227-237.

Castanera, D., Barco, J.L., Díaz-Martínez, I., Herrero Gascón, J., Pérez-Lorente, F. \& Canudo, J.I. 2012. Juvenile or dwarf sauropods? The case of the titanosauriform herd from Las Cerradicas tracksite (Teruel, Spain). In: Dinosaur tracks 2011 (eds Richter, A. \& Reich, M.). Universitätsverlag Göttingen, 19.

Castanera, D., Vila, B., Razzolini, N.L., Falkingham, P.L., Canudo, J.I., Manning, P.L. \& Galobart, A. 2013. Manus track preservation bias as a key factor for assessing trackmarker identity and quadrupedalism in basal ornithopods. PLoS ONE, 8, 1, e54177, doi:10.1371/ journal.pone.0054177.

Cobos, A. 2011. Los dinosaurios de Teruel como recurso para el desarrollo territorial. PhD Thesis, Universidad del País Vasco (unpublished).
Cobos, A., Alcalá, L. \& Mampel, L. 2012. Stegosaurian footprints from the Jurassic-Cretaceous transition of Teruel (Spain). In: $11^{\text {th }}$ Mesozoic Terrestrial Ecosystems. Gwangju, p. 28-29.

Cobos, A., Royo-Torres, R., Alcalá, L., Luque, L. \& Aberasturi, A. 2008. Nuevos datos de las icnitas de dinosaurios en la Formación Villar del Arzobispo (Teruel). In: XXIV Jornadas de la Sociedad Española de Paleontología. Colunga, Asturias, p. 25-26.

Cobos, A., Royo-Torres, R., Luque, L., Alcalá, L. \& Mampel, L. 2010. An Iberian stegosaurs paradise: The Villar del Arzobispo Formation (Tithonian-Berriasian) in Teruel (Spain). Palaeogeography, Palaeoclimatology, Palaeoecology, 293, 223-236.

Cuenca-Bescós, G., Canudo, J.I. \& Ruiz-Omeñaca, J.I. 1997. Dinosaurios del tránsito Jurásico-Cretácico en Aragón. V Jornadas Aragonesas de Paleontología "Vida y ambientes del Jurásico". In: Homenaje científico a la Prof. Asunción Linares. Ricla, Zaragoza, p. 193-221.

FCPT-IDPI (Fundación Conjunto Paleontológico de Teruel Dinópolis-Icnitas de Dinosaurios de la Península Ibérica). 2009. Dinosaur Ichnites of the Iberian Peninsula, World Heritage Candidacy. Ministerio de Cultura de España \& Ministério do Ambiente, do Ordenamento do Território e do Desenvolvimento Regional do Portugal (unpublished).

Gascó, F., Verdú, J., Cobos, A. Royo-Torres, R. \& Alcalá, L. 2013. Los ornitópodos de Barrihonda-El Humero en la Formación Villar del Arzobispo de Riodeva (Teruel, España). In: XXIX Jornadas de la Sociedad Española de Paleontología. Córdoba, p. 149-150.

Lockley, M.G. 2009a. Some comparisons between dinosaurdominated footprint assemblages in North America and Europe. In: Actas de las IV Jornadas Internacionales sobre Paleontología de Dinosaurios y su Entorno. Salas de los Infantes, Burgos, p. 121-138.

Lockley, M.G. 2009b. New perspectives on morphological variation in tridactyl footprints: clues to wide spread convergence in developmental dynamics. Geological Quarterly, 53, 4, 415-432.

Lockley, M. \& Meyer, C. 1999. Dinosaur Tracks and Other Fossil Footprints of Europe. Columbia University Press, New York.

Malafaia, E., Ortega, F., Escaso, F., Dantas, P., Pimentel, N., Gasulla, J.M., Ribeiro, B., Barriga, F. \& Sanz, J.L. 2010. Vertebrate fauna at the Allosaurus fossil-site of Andrés (Upper Jurassic), Pombal, Portugal. Journal of Iberian Geology, 36, 193-204.

Mampel, L., Cobos, A., Alcalá, L., Espílez E., Royo-Torres, R., González, A. \& Gascó, F. 2010-2011. Icnitas de dinosaurios en Aguilar del Alfambra (Teruel, España). Teruel, 93, 41-54.

Marty, D. 2008. Sedimentology, taphonomy, and ichnology of Late Jurassic dinosaur tracks from the Jura carbonate platform (Chevenez-Combe Ronde tracksite, NW Switzerland): Insights into the tidal-flat palaeoenvironment and dinosaur diversity, locomotion, and palaeoecology. GeoFocus, 21, 1-278. 
Mas, R., Alonso, A. \& Meléndez, N. 1984. La Formación Villar del Arzobispo: un ejemplo de llanuras de marea siliciclásticas asociadas a plataformas carbonatadas. Jurásico terminal (NW de Valencia y E de Cuenca). Publicaciones de Geología, Universidad Autónoma de Barcelona, 20, 175-188.

Mateus, O. \& Antunes, M.T. 2001. Draconyx loureiroi, a new camptosauridae (Dinosauria, Ornithopoda) from the Late Jurassic of Lourinhã, Portugal. Annales de Paléontologie, $87,61-73$.

Norman, D.B. 1980. On the Ornitishian dinosaur Iguanodon bernissartensis from Belgium. Mémoires de l'Institut Royal des Sciences Naturelles de Belgique, 178, 1-105.

Norman, D.B. 2004. Basal Iguanodontia. In: The Dinosauria, 2nd ed. (eds Weishampel D.B., Dodson P. \& Osmólska H.). University of California Press, Berkeley, 413-437.

Pereda-Suberbiola, X., Ruiz-Omeñaca, J.I. \& Company, J. 2009. Primera descripción de restos esqueléticos de dinosaurio ornitópodo en la Formación. Villar del Arzobispo (tránsito Jurásico-Cretácico): yacimiento de Cerrito del Olmo (Alpuente, Valencia). Geogaceta, 47, $13-16$.

Pereda-Suberbiola, X., Ruiz-Omeñaca, J.I., Hernández, J.M. \& Pujalte, V. 2006. Primera cita de un dinosaurio ornitópodo en el Cretácico Inferior (Berriasiense) del SO de la Cuenca Vasco-Cantabrica (Palencia, España). Revista de la Sociedad Geológica de España, 19, 219-231.

Pérez-Lorente, F. 2004. Las icnitas de dinosaurios de Teruel. ¡Fundamental!, 02, 13-32.
Pérez-Lorente, F. 2009. Las huellas de Galve. In: II Jornadas Paleontológicas de Galve. 50 años del descubrimiento del Aragosaurus y 20 años de su definición (ed. Instituto de Estudios Turolenses), Teruel, p. 85-114.

Pérez-Lorente, F., Cuenca-Bescós, G., Aurell, M., Canudo, J.I., Soria, A.R. \& Ruiz-Omeñaca, J.I. 1997. Las Cerradicas tracksite (Berriasian, Galve, Spain): Growing evidence for quadrupedal ornithopods. Ichnos, 5, 109-120.

Royo-Torres, R. 2009. Los dinosaurios saurópodos en la Península Ibérica. In: Actas de las IV Jornadas Internacionales sobre Paleontología de Dinosaurios y su Entorno. Salas de los Infantes, Burgos, p. 139-166.

Royo-Torres, R. \& Cobos, A. 2007. En ruta con los dinosaurios de Teruel. ;Fundamental!, 11, 65-76.

Royo-Torres, R., Cobos, A. \& Alcalá, L. 2006. A Giant European Dinosaur and a New Sauropod Clade. Science, 314, 1925-1927.

Royo-Torres, R., Gascó, F. \& Cobos, A. 2012. Dinosaurs from Zaragoza province (Iberian Range, Spain). ;Fundamental!, 20, 215-218.

Sarjeant, W.A.S., Delair, J.B. \& Lockley, M.G. 1998. The footprints of Iguanodon: a History and Taxonomic Study. Ichnos, 6, 183-202.

Suñer, M. \& Martín, M. 2009. Un nuevo yacimiento del tránsito Jurásico-Cretácico de Alpuente (Los Serranos, Valencia, España): resultados preliminares. Paleolusitana, $1,441-447$. 